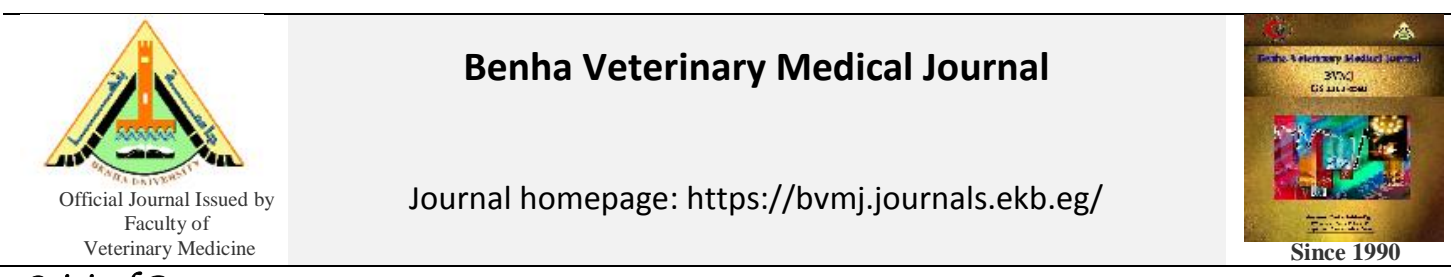

Original Paper

\title{
The effect of different disinfectants against some food poisoning bacteria at abattoir level
}

Hassanien, F.S. ; Shaltout, F.A.; Fahmey, M.Z. and Elsukkary, H.F.

Food Control Dept., Fac. Vet. Med., Benha University, Egypt

ARTICLE INFO

\begin{tabular}{l}
\hline Keywords \\
beef \\
local \\
imported \\
Bacteriological \\
evaluation \\
Received $17 / 06 / 2020$ \\
Accepted 19/07/2020 \\
Availa6le On-Line \\
01/10/2020 \\
\hline
\end{tabular}

\begin{abstract}
Ninety random samples of fresh beef were collected from cattle carcasses slaughtered at 3 different abattoirs at Menoufia governorate (30 of each) in 2018. The sampling site was represented by neck region (chuck) of each carcass. The obtained results revealed the efficacy of five different disinfectants against some food poisoning bacteria including E. coli $\mathrm{O} 26$ : H11, S. Typhimurium and Klebsiella pneumonia which were isolated and serotyped at abattoir level. In vitro infected samples $\left(3.0 \times 10^{6} / \mathrm{cm}^{2}\right)$ were examined under the effect of different concentrations of disinfections within contact time 120 minutes. Disinfectant A at concentration $1 \%$ was effective against $100 \%$ of E. coli O26: $\mathrm{H} 11$ and Klebsiella pneumoniae, while concentration $1.5 \%$ of disinfectant A was required for elimination of $S$. Typhimurium, followed by B, C, D and E disinfectants, respectively. On the other hand, D and $\mathrm{E}$ disinfectants even in $2 \%$ concentration and contact time 120 minutes reduced $99 \%$ of the infection.
\end{abstract}

\section{INTRODUCTION}

Food of animal origin, especially raw meat, fish, milk and eggs, requires special treatment during processing, preparation, transportation and storage to avoid contamination. Meat is a good media for growth and multiplication of microorganisms leading to several diseases which might transmitted through the consumption. In developing countries, the external contamination of meat in the abattoir is considered a problem due to large numbers of potential sources of contaminating microorganisms (Davis et al., 2002). The bacterial load was associated with poor sanitation procedures (Soliman et al., 2009). The effective use of disinfectants is of great importance to many control measures. (MacLaren et al., 2001). Routine disinfection in the slaughterhouse depends on the usage of effective and efficient disinfectants against microorganisms which don't affect the meat or its marketability (Sander et al., 2002). The temperature, pressure, organic matter, surface material type, hydrogen ion concentration $(\mathrm{pH})$ and contact time are factors affecting on the disinfection process ,so it is necessary to understand the nature of the disinfectant and the environmental uses (Jang et al., 2014). Determining the practical use of the disinfectant it is important to identify the type of disinfectants that would be tested under the same conditions. The laboratory bacterial suspensions were used for determining the efficacy of the tested disinfectants (Bloomfeld et al., 1991; Soliman et al., 2016). The aim of this study was to investigate, in vitro disinfectant activity of five disinfectants named A, B, C, D and E which were frequently used in abattoirs to assess their efficacy against some isolated food poisoning bacteria.

\section{MATERIAL AND METHODS}

\subsection{Collection of samples}

Ninety random samples of fresh beef were collected from cattle carcasses slaughtered at 3 different abattoirs at Menoufia governorate (30 of each). The sampling site was represented by neck region (chuck) of each carcass and the weight of each sample was approximately $100 \mathrm{~g}$. Each sample was kept in a separated sterile plastic bag and transferred in ice box to the laboratory under complete aseptic conditions without undue delay.

2.2. In vitro disinfectant efficacy against bacterial pathogens:

2.2.1. Preparation of test strains (Sutton et al., 2002):

Standardized stable suspensions of test strains represented by E. coli (O26: H11), Salmonella Typhimurium and Klebsiella pneumoniae were prepared by seed-lot culture maintenance techniques (seed-lot systems).

2.2.2. Preparation of disinfectant Agent (Linton et al., 1987):

2.2.2.1. Disinfectant agents:

$\mathrm{A}, \mathrm{B}, \mathrm{C}, \mathrm{D}$ and $\mathrm{E}$ disinfectants were prepared as per production procedure and/or supplier guideline so that the test solution is made to its final dilution using USP purified water with $\mathrm{pH}$ 5.0-7.0 from the facility distribution water system.

2.2.2.2. Antimicrobial effectiveness test:

Disinfectants were diluted to $90 \%$ of the working concentration with definite volume of previously settled

\footnotetext{
* Corresponding author: Hassan Fehr Abdelkader Elsukkary, hassanfehr@ gmail.com,
} 
microbial suspension during test as a matter of challenge to account for dilution error and variability during actual situation of biocidal agent preparation. Finally, the concentrations to be used were $1 \%, 1.5 \%$ and $2 \%$ with exposure times of 30, 60, 90 and 120 minutes.

\subsubsection{In vitro surface challenge test (Clontz, 2008):}

The challenge test was modified, so the wet application method of microorganisms to coupon surfaces was adopted as dryness will act in favor of disinfectant which may overestimate its true effectiveness.

\subsection{Statistical analysis:}

The obtained results were statistically evaluated by application of Analysis of Variance (ANOVA) test according to Feldman et al. (2003).

\section{RESULTS}

Results in table (1) showed the in vitro disinfectants efficacy against $E$. coli $\mathrm{O} 26$ : $\mathrm{H} 11\left(3.0 \times 10^{6} / \mathrm{cm}^{2}\right)$ infected samples within contact time 120 minutes. Disinfectant A was the most effective in our study at concentration $1 \%$ against E. coli O26: H11, followed by B disinfectant at concentration $1.5 \%$ and $\mathrm{C}$ disinfectant at concentration $2 \%$, while $\mathrm{D}$ and $\mathrm{E}$ disinfectants even at concentration $2 \%$ were efficient against $99.9 \%$ and $99.7 \%$, respectively. Moreover, lower concentration of disinfectants as B disinfectant $1.5 \%$ (99\%), C disinfectant $1 \%$ and $1.5 \%(99.9 \%)$, D disinfectant $1 \%(99.7 \%), 1.5 \%(99.8 \%$.) \& $2 \%$ (99.9) and E disinfectant $1 \%(98.2 \%), 1.5 \%(99.3 \%) \& 2 \%(99.7 \%)$ was associated with a reduction in the infection.

Table 1 Efficacy against $E$. coli O26: $\mathrm{H} 11 \quad\left(3.0 \times 10^{6} / \mathrm{cm}^{2}\right)$ at different concentrations within contact time 120 minute.

\begin{tabular}{lcccccc}
\hline \multirow{2}{*}{ Type of disinfectant } & \multicolumn{5}{c}{ Concentration \&efficacy\% of disinfectant } \\
\cline { 2 - 7 } & $1 \%$ & $\mathrm{R} \%$ & $1.5 \%$ & $\mathrm{R} \%$ & $2 \%$ & $\mathrm{R} \%$ \\
\hline $\mathrm{A}$ & - & 100 & - & 100 & - & 100 \\
$\mathrm{~B}$ & $6.4 \times 10^{2}$ & 99.9 & - & 100 & - & 100 \\
$\mathrm{C}$ & $1.9 \times 10^{3}$ & 99.9 & $1.0 \times 10^{3}$ & 99.9 & - & 100 \\
$\mathrm{D}$ & $5.4 \times 10^{3}$ & 99.7 & $6.8 \times 10^{3}$ & 99.8 & $2.9 \times 10^{3}$ & 99.9 \\
$\mathrm{E}$ & $2.2 \times 10^{4}$ & 98.2 & $2.5 \times 10^{4}$ & 99.3 & $7.4 \times 10^{3}$ & 99.7 \\
\hline Active ingredients of Disinfectants. A= Sodium hypochlorite, Sodium carbonate B= \\
Chlorine dioxide. C=Phenol, sodium sulphate salt, anionic surfactants. D= Potassium \\
peroxymonosulfate and Sodium chloride. E= Iodine, phosphoric acid, sulphuric acid
\end{tabular}

The results in table (2) demonstrated the effect of disinfectants against in vitro infected samples with $S$. Typhimurium. Disinfectant A was effective at $1.5 \%$, followed by B disinfectant (2\%) through 120 minutes contact time, while at the maximum concentration $2 \%$ of C, D and E disinfectants were $99 \%, 99.8 \%$ and $99.6 \%$ efficacy against $S$. Typhimurium. It was noticed that B and C disinfectants showed the same efficacy at both concentrations $1 \%$ and $1.5 \%$ (99.9\% and $99.8 \%$ ) for each disinfectant, respectively. While, lower concentrations revealed A disinfectant $1 \%$ (99.9), B disinfectant $1 \%$ and $1.5 \%$ (99.9\%), while $\mathrm{C}$ disinfectant $1 \%$ and $1.5 \%(99.8 \%)$ $\& 2 \%(99.9 \%)$, D disinfectant $1 \%(99.0 \%), 1.5 \%(99.6 \%)$ \& $2 \%(99.8 \%)$ and $\mathrm{E}$ disinfectants $1 \%(98.2 \%), 1.5 \%$ $(99.0 \%) \& 2 \%(99.6 \%)$. It was noticed that A disinfectant was the disinfectant of choice followed by B, C and D disinfectant which showed the same efficacy at concentration $1 \%$ and $1.5 \%$ against S. Typhimurium.
Table 2 Disinfectant efficacy against S. Typhimurium $\left(3.0 \times 10^{6} / \mathrm{cm}^{2}\right)$ at different concentrations within contact time 120 minute.

\begin{tabular}{lllllll}
\hline \multirow{2}{*}{ Type of disinfectant } & \multicolumn{5}{c}{ Concentration\& efficacy \% of disinfectant } \\
\cline { 2 - 7 } & $1 \%$ & $\mathrm{R} \%$ & $1.5 \%$ & $\mathrm{R} \%$ & $2 \%$ & $\mathrm{R} \%$ \\
\hline $\mathrm{A}$ & $5.0 \times 10^{2}$ & 99.9 & - & 100 & - & 100 \\
$\mathrm{~B}$ & $1.1 \times 10^{3}$ & 99.9 & $4.0 \times 10^{2}$ & 99.9 & - & 100 \\
$\mathrm{C}$ & $6.5 \times 10^{3}$ & 99.8 & $3.5 \times 10^{3}$ & 99.8 & $8.0 \times 10^{2}$ & 99.9 \\
$\mathrm{D}$ & $2.9 \times 10^{4}$ & 99.0 & $9.8 \times 10^{3}$ & 99.6 & $4.3 \times 10^{3}$ & 99.8 \\
$\mathrm{E}$ & $5.3 \times 10^{4}$ & 98.2 & $3.0 \times 10^{4}$ & 99.0 & $9.2 \times 10^{3}$ & 99.6 \\
\hline
\end{tabular}

The results in table (3) showed the effect of disinfectant against Klebsiella pneumonia infected samples. A and B at concentration $1 \%$ were effective in $(100 \%)$ disinfection activity, followed by $\mathrm{C}$ disinfectant $1.5 \%$ and $\mathrm{D}$ disinfectant $2 \%$, while $\mathrm{E}$ disinfectant even in concentration $2 \%$ was effective on $(99.9 \%)$. Disinfectant $\mathrm{C}$ and D showed the same efficacy at concentration $1 \%$. Moreover, disinfectant $\mathrm{D}$ and $\mathrm{E}$ showed the same results at concentration $1 \%$ and $1.5 \%$ were $99.9 \%$ and $99.8 \%$ respectively. C disinfectant at concentration $1 \%(99 \%), \mathrm{D}$ disinfectant at concentration $1 \% \& 1.5 \%$ were effective against $99.9 \%$ and $\mathrm{E}$ disinfectant at concentration $1 \%$ \& $1.5 \%$ revealed $99.8 \%$ efficacy against examined microorganisms.

Table 3 Disinfectant efficacy against Klebsiella pneumoniae $\left(3.0 \times 10^{6} / \mathrm{cm}^{2}\right)$ at different concentrations within contact time 120 minute.

\begin{tabular}{lllllll}
\hline \multirow{2}{*}{ Type of disinfectant } & \multicolumn{6}{c}{ concentration \& efficacy \% of disinfectant } \\
\cline { 2 - 6 } & $1 \%$ & $\mathrm{R} \%$ & $1.5 \%$ & $\mathrm{R} \%$ & $2 \%$ & $\mathrm{R} \%$ \\
\hline $\mathrm{A}$ & - & 100 & - & 100 & - & 100 \\
$\mathrm{~B}$ & - & 100 & - & 100 & - & 100 \\
$\mathrm{C}$ & $3.0 \times 10^{2}$ & 99.9 & - & 100 & - & 100 \\
$\mathrm{D}$ & $2.1 \times 10^{3}$ & 99.9 & $1.0 \times 10^{2}$ & 99.9 & - & 100 \\
$\mathrm{E}$ & $5.6 \times 10^{3}$ & 99.8 & $3.8 \times 10^{3}$ & 99.8 & $7.0 \times 10^{2}$ & 99.9 \\
\hline
\end{tabular}

\section{DISCUSSION}

Many defects on the slaughtering process were responsible for microbial contamination and microbial transmission of meat that occur due to inadequate abattoir facilities, insufficient training practices and poor hygienic and sanitary practices with insufficient anti mortem and postmortem inspection (FAO., 2010). The production, distribution and consumption of safe meat protect human health, proper cleaning of slaughterhouse and sanitation of the floor, walls and equipment should occur daily under Sanitary standard operation procedures (SSOPs) for cleaning and sanitation. The hides and skin during flaying, butchers tools, intestinal and stomach contents during evisceration, using of poor-quality water for carcasses washing, poor personal hygiene and contaminated meat carriers were the major causes of carcass contamination (Khan, 2018). The cell density, growth rate and the limiting nutrient are factors affecting the susceptibility of the members of Enterobacteriaceae to certain antiseptics and disinfectants (Bjergbæk et al., 2008). The bactericidal effects of disinfectants varied between different types of disinfectants so the disinfectants should be investigated prior to using in the meat industry (Møretrø et al., 2013). The present study focused on evaluating the efficacy of five types of disinfectants against bacterial pathogens at abattoir level. 
The results in table (1) revealed that disinfectant $\mathrm{A}$ at concentration (1\%) was effective against examined samples of $E$. coli O26: $\mathrm{H} 11$ within 120 minutes contact time followed by B disinfectant at concentration $(1.5 \%)$ and $\mathrm{C}$ disinfectant at concentration (2\%), while, D and $\mathrm{E}$ disinfectants showed lower effect that agreed with Kamal (2019), who showed that some microorganisms as E.coli and Salmonella were able to survive and detected in environmental samples of the slaughterhouse and in carcass samples (Carrique-Mas and Davies, 2008).

The results in table (2) revealed that the efficacy of disinfectants against S. Typhimurium, disinfectant A $1.5 \%$ and B (2\%) agreed with Ibrahim and Ali (2002) and Bridier et al. (2019). Lower disinfection activity obtained by C, D and $\mathrm{E}$ disinfectants that agreed with Chapman (2003) and Campos et al. (2012), who reported that bacteria can develop resistance to disinfectants based on phenol, chlorine and alcohol compounds. The holes found in floors and walls of the abattoir make it's difficult for the penetration of disinfectant solutions. The biofilms created by Salmonella can make the action of the disinfectants more difficult (Marin et al., 2009).

The results recorded in table (3) revealed that A disinfectant at concentration (1\%) and B disinfectants at concentration $(1.5 \%)$ then $\mathrm{C}$ and $\mathrm{D}$ disinfectants had higher disinfection activity against Klebsiella pneumoniae. These agreed with Montagna et al. (2019). It was noticed that higher concentrations and contact time lead to proper disinfection activity that agreed with Soliman et al. (2016) and Kamal et al. (2019). The hygienic measures at the slaughterhouse were pointed to prevent the transmission of the microorganisms to and from animal carcasses and slaughterhouse environment even with application of satisfactory cleaning procedures or using strong disinfectants Soliman et al. (2016). The miss use of disinfectants, including lower doses, lack of change, and other factors lead to the development of disinfectant microbial resistance (Davies and Wales. 2019).

\section{CONCULSION}

In conclusion, hygienic measures of proper cleaning and disinfection should be applied to prevent carcass and meat contamination and subsequent production of noncontaminated and safe meat at abattoir.

\section{REFERENCES}

1. Bjergbæk, L.A.; Haagensen, J.A.J.; Molin, S.; Roslev, P. (2008): Effect of oxygen limitation and starvation on the benzalkonium chloride susceptibility of Escherichia coli. J. Appl. Microbiol. 105(5): 1310-1317.

2. Bridier, A.; Le Grandois, P.; Moreau, M.; Prénom, C. ;Le Roux,A.; Feurer ,C. and Soumet,C. (2019): Impact of cleaning and disinfection procedures on microbial ecology and Salmonella antimicrobial resistance in a pig slaughterhouse. Sci Rep 9, https://doi.org/10.1038/s41598019-49464-8.

3. Bloom Feld, S. F.; Arther, M.; Looney, E.; Begun, K.; Patel, H. (1991): Comparative testing of disinfectant and antiseptic products using proposed European suspension testing methods. Lett. Appl. Microbiol. 13(5): 233-237

4. Campos, G.B.; Souza, S.G.; Lob, O.T.N.; Da Silva, D.C.; Sousa, D.S.; Oliveira, P.S.; Santos, V.M.; Amorim, A.T.; Farias, S.V.; Cruz, M.P. (2012): Isolation, molecular characteristics and disinfection of methicillin-resistant.
Staphylococcus aureus from ICU units in Brazil. New Microbiol. 35, 183-190.

5. Chapman, J.S. (2003) Disinfectants resistance mechanisms, cross-resistance, and co-resistance. Int. Biodeterior. Biodegrad., 51, 271-276.

6. Clontz, L. (2008): Microbial Limit and Bioburden Tests: Approaches and Global Requirements, second edition, CRC Press New York, USA.

7. Davis, J.R.; Apple, J.K.; Hellwig, D.H.; Kegley, E.B. and Pohlman, F.W. (2002): The effects of feeding broiler litter on microbial contamination of beef carcasses. J. Bioresour. Technol., 84: 191-196.

8. Davies, R. and Wales, A. (2019) Antimicrobial resistance on farms: A review including biosecurity and the potential role of disinfectants in resistance selection. Comp. Rev. Food Sci. Food Saf, 18(3): 753-774.

9. Food and Agriculture Organization "FAO"(2010): Abattoir Development in: Options and designs for hygienic basic and medium sized abattoirs .Rome: Food and Agriculture Organization of The United Nations.

10. Feldman, D.; Ganon, J.; Haffman, R. and Simpson, J. (2003): The solution for data analysis and presentation graphics. $2^{\text {nd }}$ Ed., Abacus Lancripts, Inc., Berkeley, USA.

11. Ibrahim, S. H. and Ali, R.A. (2002): Effect of some dis infectants on well water borne pathogens and influence of cologne injury on virulence. J. Egypt, Vet. Med., 62(3):7-27.

12. Jang, Y.; Lee, J.; So, B.; Lee, K.; Yun, S.; Lee, M. and Choe, N. (2014): Evaluation of changes induced by temperature, contact time, and surface in the efficacies of disinfectants against avian influenza virus. Poult. Sci., 93(1):70-76.

13. Kamal, M.A.; Khalaf, M.A.; Ahmed, Z.A.M. and El Jakee, J. (2019): Evaluation of the efficacy of commonly used disinfectants against isolated chlorine-resistant strains from drinking water used in Egyptian cattle farms, Veterinary World, 12(12): 2025-2035.

14. Khan, A.M. (2018): Significance of hygiene meat for public health, PubMed. Edu. PMAS Arid Agriculture University Rawalpindi. Presented by 14-ARID-2022 14-ARID-2025 14ARID-2031 14-ARID-2032.

15. Linton, Y.; Hugo, W. B. and Russel, A. D. (1987): Disinfection: In Veterinary and Farm Animal Practice. $2^{\text {nd }}$ Ed. Oxford, London, Edinburgh, Blackwell Scientific Publication, UK

16. MacLaren. I.; Wales, A.; Breslin, M. and Davies, R. (2001): Evaluation of commonly-used farm disinfectants in wet and dry models of salmonella farm contamination. Avian Pathol. 40(1): 33-42

17. Marin, C.; Hernandiz, A.; Lainez, M. (2009) Bioflm development capacity of Salmonella strains isolated in poultry risk factors and their resistance against disinfectants. Poult. Sci. 88(2): 424-431.

18. Møretrø, T.; Langsrud, S. and Heir, E. (2013): Bacteria on meat abattoir process surfaces after sanitation: characterization of survival properties of Listeria monocytogenes and the commensal bacterial flora. Advances in Microbiology, 3, 255-264

19. Sander, J.E.; Hofacre, C.L.; Cheng, I.H. and Wyatt, R.D. (2002): Investigation of resistance of bacteria from commercial poultry sources to commercial disinfectants. Avian Dis. 46(4): 997-1000.

20. Soliman, E.; Moawed, S. and Ziaan, A. M .G. (2016) Assessing cleaning and disinfection regime in a slaughterhouse against carcasses contamination. Advances in Animal and Veterinary Sciences 4(9):449-457.

21. Soliman, E.S.; Taha, E.G.; Sober, M.A.A. and Reddy, P.G. (2009): Efficacy of some commercial disinfectants on Salmonella enterica serovar typhimurium. Am. J. Anim. Vet. Sci. 4(3): 58-64

22. Sutton, S.V.; Proud, D.W.; Rachui, S. and Brannan, D.K. (2002): Validation of microbial recovery from disinfectants. PDA. J. Pharmaceutical Sci. and Technol., 56 (5): 255-266. 